\title{
Effect of different levels of dietary molybdenum on copper and Mo metabolism in sheep fed on high levels of $\mathrm{Cu}$
}

\author{
BY J. B. J. VAN RYSSEN AND W. J. STIELAU \\ Department of Animal Science, University of Natal, PO Box 375, Pietermaritzburg 3200, \\ South Africa
}

(Received 8 May 1980 - Accepted 9 September 1980)

\begin{abstract}
1. Distribution of copper and molybdenum was followed in the body tissues of sheep fed on high levels of $\mathrm{Cu}(82 \mathrm{mg} \mathrm{Cu} / \mathrm{sheep}$ per d), sulphur (3.77 $\mathrm{g} \mathrm{S} /$ sheep per d) and different levels of Mo $(0.620 .8,38.4 \mathrm{and} 58.5 \mathrm{mg}$ Mo/sheep per d).

2. Liver Cu content decreased as Mo intake increased from 0.6 to $38.4 \mathrm{mg} / \mathrm{d}$, but increased again at high intakes of Mo. With an Mo intake of $58.5 \mathrm{mg} / \mathrm{d}$, the $\mathrm{Cu}$ content of liver, kidney, lung, spleen and muscle tissue was significantly higher than with an intake of $20.8 \mathrm{mg} \mathrm{Mo} / \mathrm{d}$. The trend of increased Cu concentrations in kidneys and plasma was already evident at an Mo intake of $38.4 \mathrm{mg} / \mathrm{sheep}$ per d.

3. High positive correlations were observed between $\mathrm{Cu}$ and $\mathrm{Mo}$ in both the kidney cortex and medulla of the sheep at the two highest Mo treatments.

4. At constant $S$ intake, Mo concentrations in the tissues tended to increase in proportion to Mo intakes. No indication of any detrimental effect due to the accumulation of Mo in the tissues was observed.

5. It was suggested that in the presence of an abundance of $\mathrm{Mo}, \mathrm{Cu}$ and $\mathrm{S}$, compounds containing these minerals in metabolically unavailable forms accumulate in the body, first in the kidneys, but eventually also in the other tissues of the sheep.
\end{abstract}

It is well established that molybdenum in the presence of sulphur reduces the copper concentration in the livers of sheep (Dick, 1954; Wynne \& McClymont, 1956; Suttle, 1974). Suttle (1975) pointed out that the extent and risk of the depression of $\mathrm{Cu}$ concentration in liver by Mo supplementation depends on the $\mathrm{Cu}$ status of the liver, the duration of Mo feeding and the dietary levels of $\mathrm{Cu}$ and Mo during this period. However, with Mo intakes of between 20 and $100 \mathrm{mg} /$ sheep per d Dick (1954) observed very little change in hepatic $\mathrm{Cu}$ content, though in cattle Vanderveen \& Keener (1964) and Huber et al. (1971) observed decreased levels of hepatic $\mathrm{Cu}$ at higher Mo intakes.

A further consequence of the $\mathrm{Cu}-\mathrm{Mo}-\mathrm{S}$ interaction in the body is the increase in $\mathrm{Cu}$ concentration of the plasma and kidneys at high Mo intakes (Dick, 1956; Suttle \& Field, 1968; Smith \& Wright, 1975; Van Ryssen, 1979). These changes in plasma and kidney $\mathrm{Cu}$ levels were described by Suttle (1974) as true systemic effects of the $\mathrm{Cu}-\mathrm{Mo-S}$ interaction in sheep. However, the relative importance of these so-called systemic effects was considered to be rather small (Suttle, 1975).

It has been observed that hepatic $\mathrm{Cu}$ concentrations may remain at high levels (Ross, 1970) and that sheep can die of $\mathrm{Cu}$ toxicity months after the withdrawal of all additional $\mathrm{Cu}$ from their diets (Bracewell, 1958; Barden \& Robertson, 1962). The reduction of hepatic $\mathrm{Cu}$ content is therefore essential if $\mathrm{Cu}$ accumulation has already taken place in the liver. This can be achieved by exploiting the systemic interactions between $\mathrm{Cu}, \mathrm{Mo}$ and $\mathrm{S}$.

Relatively little information is available on the effect of different levels of Mo supplementation on $\mathrm{Cu}$ metabolism under conditions of $\mathrm{Cu}$ toxicity where results have not been confounded by other treatment effects. A trial was carried out in which sheep received different levels of dietary Mo as well as high levels of $\mathrm{Cu}$ and $\mathrm{S}$ to follow the effect of these 
treatments on the $\mathrm{Cu}$ and Mo metabolism in the body once $\mathrm{Cu}$ had accumulated in the liver.

\section{EXPERIMENTAL}

\section{Animals, treatments and procedure}

Forty South African Mutton Merinos (twenty wethers and twenty ewes), approximately 1 year of age, were randomly allocated within sex to five groups. During a pre-experimental period of $42 \mathrm{~d}$ all groups received a basic ration high in $\mathrm{Cu}$ and $\mathrm{S}$ but low in $\mathrm{Mo}$. At the end of this period one group, the pre-experimental slaughter group $(\mathrm{Pr}-\mathrm{X})$, was slaughtered, while the other groups were fed on rations containing different levels of Mo for a further 193 d: no-Mo, low-Mo, medium-Mo, high-Mo.

The groups were group-fed once daily in concrete-floored pens. Tap water was available ad lib. The ration consisted of milled hay (predominantly Themeda triandra) and a concentrate mixture comprising (g/kg): 355 maize meal, 299 sunflower-oil-cake meal, 299 sterilized poultry manure, 30 urea, 15 hydrated sodium sulphate, 0.955 cupric sulphate pentahydrate. Different levels of $\mathrm{Mo}$ in the form of $\left(\mathrm{NH}_{4}\right)_{6} \mathrm{MO}_{7} \mathrm{O}_{24} \cdot 4 \mathrm{H}_{2} \mathrm{O}$ were included in the concentrate mixture according to treatment resulting in Mo concentrations $(\mathrm{mg} / \mathrm{kg})$ in the experimental rations of: 0.6 no-Mo, 21.4 low-Mo, 39.6 medium-Mo, 60.3 high-Mo.

The sheep were weighed once monthly before the daily feeding and jugular blood samples were taken at regular intervals throughout the trial. At the end of the trial a wool sample was collected from the side of each sheep, the dirty tips were cut off and the remainder washed and the fat extracted. At slaughter, livers, kidneys, spleens, lungs, hearts and $50 \times 50 \mathrm{~mm}$ muscle samples from the $\mathrm{M}$. longissimus dorsi were collected from the sheep. Samples were dried at $80^{\circ}$ for $4 \mathrm{~d}$. These dried samples were ground and kept for further analyses. Fat extractions with diethyl ether were done on the heart and muscle tissues before analysis.

\section{Analytical methods}

The following analyses were performed according to the methods described by Van Ryssen \& Stielau (1980): dietary Mo, $\mathrm{Cu}$, zinc, iron, manganese, S, calcium, phosphorus and crude protein (nitrogen $\times 6.25$ ); Mo and total $\mathrm{Cu}$ in organs and plasma; packed cell volume (PCV) and haemoglobin $(\mathrm{Hb})$ in whole blood.

Erythrocyte (RBC) counts on whole blood were done using a Coulter counter (Coulter Electronics, Inc. Hialeah, Florida). Serum aspartate aminotransferase $(E C 2.6 .1$. 1; GOT) and lactate dehydrogenase $(E C 1.1 .1 .27 ; \mathrm{LDH})$ levels were determined using Boehringer Mannheim standard kits (Boehringer Mannheim GmbH Diagnostica) on a Gemsaec Fast Analyser (Electro-Nucleonics). Plasma arginase (EC 3.5.3.1) was estimated according to the method described by Schwartz (1971), total serum protein and albumin by the Biuret method described by Cornelius \& Karneko (1963) and direct-reacting $\mathrm{Cu}$ in plasma according to the method of Suttle \& Field (1968).

\section{Statistical analyses}

Statistical analyses ( $F$ test and Student's $t$ test) were done according to the methods described by Rayner (1967). Where differences were large and obviously different, no statistical comparisons were considered necessary, though for the sake of simplicity in Tables 1 and 2, these differences are indicated as being significant according to the $F$ test.

\section{RESULTS}

Food intakes and composition of ration

Each sheep consumed an average of $274 \mathrm{~g}$ dry matter (DM) in the form of the concentrate mixture and $698 \mathrm{~g}$ DM as hay $/ \mathrm{d}$. The average Mo intakes $(\mathrm{mg} / \mathrm{d})$ were: $0.6 \mathrm{no}-\mathrm{Mo}, 20.8$ 
Table 1. The influence of different levels of molybdenum intake on the concentration of copper in the tissues and wool of sheep fed on high levels of $\mathrm{Cu}$

\begin{tabular}{|c|c|c|c|c|c|c|}
\hline $\begin{array}{ll}\text { Treatment groups } & \ldots \\
\text { Treatment no. ... } & \\
\text { Mo intake (mg/d) } & \ldots\end{array}$ & $\begin{array}{c}\text { Pr-X } \\
1 \\
0 \cdot 2\end{array}$ & $\begin{array}{l}\text { No-Mo } \\
2 \\
0.6\end{array}$ & $\begin{array}{c}\text { Low-Mo } \\
3 \\
20 \cdot 8\end{array}$ & $\begin{array}{c}\text { Medium-Mo } \\
4 \\
38 \cdot 4\end{array}$ & $\begin{array}{c}\text { High-Mo } \\
5 \\
58 \cdot 5\end{array}$ & $\begin{array}{l}\text { Effect of } \\
\text { treatment }\end{array}$ \\
\hline \multicolumn{7}{|l|}{ Liver } \\
\hline mg/kg DM & 608 & 987 & 812 & 660 & 835\{ & \multirow[t]{2}{*}{$\begin{array}{l}4<2 \\
1<2,5^{*}\end{array}$} \\
\hline \multicolumn{6}{|l|}{ Kidney cortex } & \\
\hline $\begin{array}{l}\mathrm{mg} / \mathrm{kg} \mathrm{DM} \\
\mathrm{SEM}\end{array}$ & $\begin{array}{l}16 \\
0.8\end{array}$ & $\begin{array}{l}26 \\
1.9\end{array}$ & $\begin{array}{c}26 \\
2 \cdot 3\end{array}$ & $\begin{array}{l}94 \\
15 \cdot 2\end{array}$ & $\begin{array}{l}236 \\
36 \cdot 6\end{array}$ & $5>4>3,2,1$ \\
\hline \multicolumn{7}{|l|}{ Kidney medulla } \\
\hline $\begin{array}{l}\mathrm{mg} / \mathrm{kg} \mathrm{DM} \\
\text { SEM }\end{array}$ & - & $\begin{array}{l}8.2 \\
0.9\end{array}$ & $\begin{array}{l}8 \cdot 4 \\
0.3\end{array}$ & $\begin{array}{r}14.9 \\
1.5\end{array}$ & $\begin{array}{r}40 \cdot 4 \\
4 \cdot 4\end{array}$ & $5>4>3,2$ \\
\hline \multicolumn{7}{|l|}{ Lungs } \\
\hline $\begin{array}{l}\mathrm{mg} / \mathrm{kg} \mathrm{DM} \\
\text { SEM } \\
\text { Spleen }\end{array}$ & $\begin{array}{r}13.0 \\
0.8\end{array}$ & $\begin{array}{r}11 \cdot 5 \\
0 \cdot 6\end{array}$ & $\begin{array}{r}11.5 \\
0.4\end{array}$ & $\begin{array}{r}12 \cdot 5 \\
0.5\end{array}$ & $\begin{array}{r}17.4 \\
0.9\end{array}$ & $5>4,3,2,1$ \\
\hline $\mathrm{mg} / \mathbf{k g ~ D M}$ & $3 \cdot 7$ & $2 \cdot 2$ & $4 \cdot 1$ & $3 \cdot 7$ & 13.0\{ & \multirow[t]{2}{*}{$\begin{array}{l}5>4,3,2,1 \\
2<4^{*}, 3,1^{*}\end{array}$} \\
\hline \multicolumn{6}{|l|}{ Muscle, $L$ dorsi (fat-free) } & \\
\hline $\mathrm{mg} / \mathrm{kg} \mathrm{DM}$ & 6.2 & $5 \cdot 0$ & $4 \cdot 6$ & $5 \cdot 6$ & \multicolumn{2}{|c|}{$6 \cdot 1\left\{\begin{array}{l}5>3,2^{*} \\
1>3^{*}\end{array}\right.$} \\
\hline SEM & 0.5 & 0.3 & 0.3 & 0.4 & \multicolumn{2}{|c|}{0.2} \\
\hline $\begin{array}{l}\text { Muscle, heart (fat-free) } \\
\text { mg/kg DM } \\
\text { SEM }\end{array}$ & $\begin{array}{r}19.4 \\
0.5\end{array}$ & $\begin{array}{r}18.8 \\
0.9\end{array}$ & $\begin{array}{r}18.8 \\
0.6\end{array}$ & $\begin{array}{r}22 \cdot 6 \\
0.6\end{array}$ & $\begin{array}{r}27.4 \\
0.8\end{array}$ & $5>4^{*}>3,2,1$ \\
\hline \multicolumn{7}{|l|}{ Wool (fat-free) } \\
\hline $\begin{array}{l}\mathrm{mg} / \mathrm{kg} \text { DM } \\
\text { SEM }\end{array}$ & - & $\begin{array}{l}6.5 \\
0.6\end{array}$ & $\begin{array}{l}6.0 \\
0.5\end{array}$ & $\begin{array}{l}6.8 \\
0.9\end{array}$ & $\begin{array}{l}5 \cdot 7 \\
0 \cdot 3\end{array}$ & NS \\
\hline
\end{tabular}

Pr-X, pre-experimental slaughter group; NS, not significant; DM, dry matter.

$* P<0.05, * * P<0.01$.

low-Mo, 38.4 medium-Mo, 58.5 high-Mo. Cu intakes of approximately $82 \mathrm{mg} / \mathrm{sheep}$ per $\mathrm{d}$ were recorded. The mean daily mineral intakes per sheep were $(\mathrm{g}): 0.06 \mathrm{Zn}, 0.30 \mathrm{Fe}, 0.24$ $\mathrm{Mn}, 3.8 \mathrm{~S}, 10.2 \mathrm{Ca}, 4.3 \mathrm{P}$. The average $\mathrm{Cu}$ : $\mathrm{Mo}$ values in the rations were: 3.9 low-Mo, 2.2 medium-Mo and 1.4 high-Mo. The average $\mathrm{Ca}: \mathrm{P}$ in the food was $2.4: 1$ while the crude protein intake per sheep was $122 \mathrm{~g} / \mathrm{d}$ during the trial.

\section{Body-weight and clinical condition}

The final average body-weights (kg) of the sheep were: 33.9 no-Mo, $35 \cdot 1$ low-Mo, 34.8 medium-Mo, 33.4 high-Mo; the differences were not statistically significant.

One sheep from the high-Mo group and one from the medium-Mo group developed diarrhoea on the 2 nd day after the inclusion of Mo in the diets. This diarrhoea lasted for $2 \mathrm{~d}$. No further incidence of diarrhoea was observed in any sheep for the rest of the trial. One ewe (low-Mo) died, apparently due to cardiovascular shock. No apparent clinical abnormality due to the high $\mathrm{Cu}$ intakes was evident.

\section{Organs and tissues}

No trend in the accumulation of minerals in organs could be related to the sex of the sheep. Values from both sexes were, therefore, pooled in the analyses. 
Table 2. The influence of different levels of molybdenum intake on the concentration of Mo in the tissues and wool of sheep fed on high levels of copper

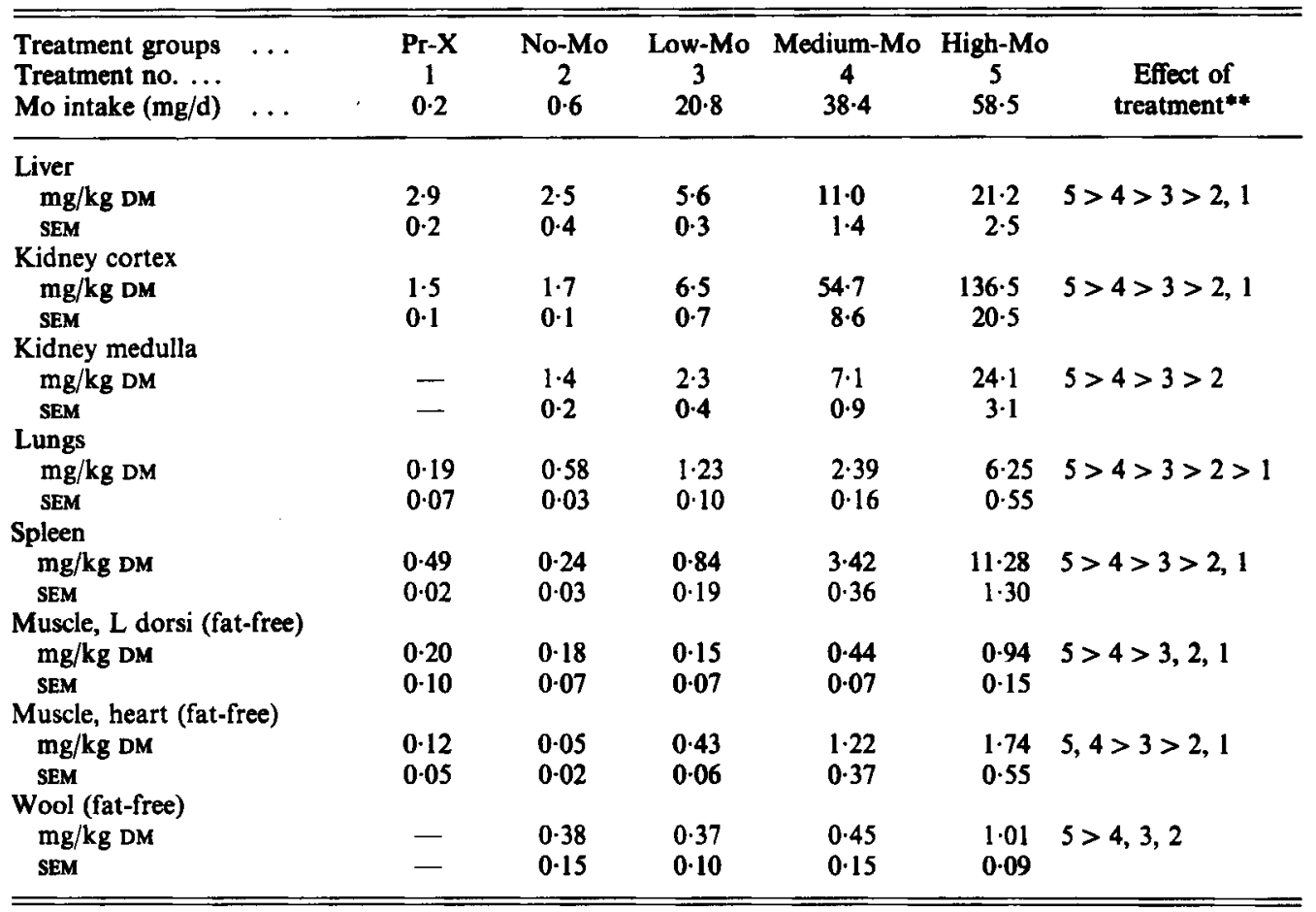

Pr-X, pre-experimental slaughter group; DM, dry matter. ** $P<0.01$

Table 3. The influence of level of molybdenum intake on copper:Mo in the kidneys of sheep fed high levels of $\mathrm{Cu}$

\begin{tabular}{lccccc}
\hline \hline & \multicolumn{2}{c}{ Cortex } & & \multicolumn{2}{c}{ Medulla } \\
\cline { 2 - 3 } \cline { 5 - 6 } Treatments & Cu:Mo & $r$ & & Cu:Mo & $r$ \\
\hline Pr-X & 10.67 & 0.03 & & - & - \\
No-Mo & 15.29 & -0.02 & & 5.86 & -0.33 \\
Low-Mo & 4.54 & 0.84 & & 3.65 & 0.06 \\
Medium-Mo & 1.71 & 0.98 & & 2.10 & 0.87 \\
High-Mo & 1.73 & 0.92 & & 1.66 & 0.88 \\
\hline
\end{tabular}

Pr-X, pre-experimental slaughter group.

$\mathrm{Cu}$. The addition of Mo up to a level of $38 \mathrm{mg} /$ sheep per $\mathrm{d}$ resulted in marked reductions in liver $\mathrm{Cu}$ content (Table 1). Despite wide variations in liver $\mathrm{Cu}$ concentrations within treatment groups, differences between the no-Mo and medium-Mo groups were statistically significant $(P<0.001)$. However, at an Mo intake of $58 \mathrm{mg} / \mathrm{sheep}$ per delevated Cu levels were again observed, higher than the liver $\mathrm{Cu}$ levels of the low-Mo group. At the $38 \mathrm{mg}$ $\mathrm{Mo} / \mathrm{kg}$ per $\mathrm{d}$ level increased kidney $\mathrm{Cu}$ levels were recorded. A slight increase in $\mathrm{Cu}$ also occurred in the heart muscle. This trend of $\mathrm{Cu}$ accumulation was obvious in all tissues with $58 \mathrm{mg} \mathrm{Mo} / \mathrm{d}$ and was very pronounced in the kidneys, especially in the kidney cortex. 
Table 4. The influence of different levels of molybdenum on the average concentrations during the experiment of total plasma copper $(\mathrm{mg} / \mathrm{l})$, direct-reacting $\mathrm{Cu}(\mathrm{DR} \mathrm{Cu} ; \mathrm{mg} / \mathrm{l})$ and total plasma Mo $(\mathrm{mg} / \mathrm{l})$ of sheep fed on high levels of $\mathrm{Cu}$

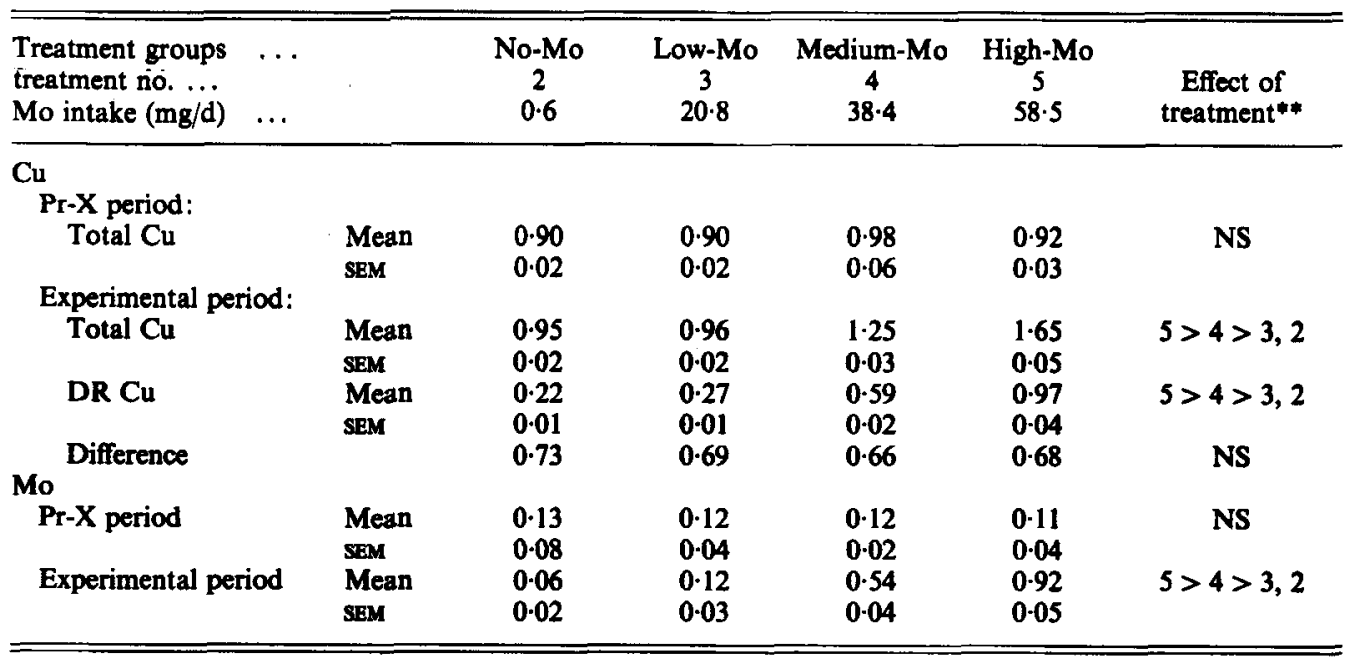

Pr-X, pre-experimental slaughter group; NS, not significant $* * P<0.01$

Mo. Any increase in level of Mo supplementation was reflected in the concentrations of Mo in the organs and tissues (Table 2). An increase of approximately $20 \mathrm{mg} \mathrm{Mo} / \mathrm{d}$ was sufficiently high to cause a statistically significant increase $(P<0.01)$ in the Mo concentration of the tissues. The most pronounced increase in Mo concentration was recorded in the kidney cortex. In this respect, $\mathrm{Cu}$ and Mo behaved similarly.

$\mathrm{Cu}: \mathrm{Mo}$. High positive correlations were observed between $\mathrm{Cu}$ and Mo concentrations in the kidney cortex in the groups receiving additional Mo (Table 3). Similarly, high correlations between $\mathrm{Cu}$ and $\mathrm{Mo}$ in the renal medulla were observed at the two highest Mo intakes.

\section{Blood analyses}

Plasma $\mathrm{Cu}$ and $\mathrm{Mo}$. Significant increases in total plasma $\mathrm{Cu}$ levels were obtained during the experimental period in the medium- and high-Mo treatments when compared with the low- and no-Mo treatments (Table 4). These differences seemed to be due mainly to the direct-reacting $\mathrm{Cu}$ fraction of plasma because the differences between total and direct-reacting $\mathrm{Cu}$ remained practically constant for all treatments.

The concentration of Mo in plasma (Table 4) followed the same pattern as the Mo concentrations in other tissues. At higher Mo intakes Mo concentrations in plasma were significantly $(P<0.01)$ increased, with a greater difference between the medium- and high-Mo intakes than between the low- and medium-Mo intakes.

Haematological measurements. Throughout the experiment the PCV, Hb levels $(\mathrm{g} / \mathrm{l})$ and RBC counts $\left(\times 10^{6} / \mathrm{ml}\right)$ remained relatively constant without any statistically significant differences between treatments or any indication of anaemia in the sheep. The average values for the experimental period were: PCV, 0.29; $\mathrm{Hb}, 109$; RBC count, 8.6.

Serum protein and enzyme levels. Total protein and albumin levels in the serum were determined on four occasions. These values remained practically constant at all analyses (Table 5). None of the differences due to treatment was statistically significant.

Serum GOT, LDH and plasma arginase levels were determined at various stages during 
Table 5. Average serum protein fractions $(\mathrm{g} / \mathrm{l})$, serum aspartate aminotransferase (EC 2.6.1.1; GOT), serum lactate dehydrogenase (EC 1.1.1.27; LDH) and plasma arginase (EC 3.5.3.1) levels in the blood of sheep receiving high levels of dietary copper and different levels of molybdenum

\begin{tabular}{|c|c|c|c|c|c|c|c|}
\hline \multirow[b]{2}{*}{$\begin{array}{l}\text { Treatment } \\
\text { groups }\end{array}$} & \multicolumn{2}{|c|}{ Protein } & \multicolumn{2}{|c|}{$\underset{\mathbf{U} / \mathbf{l}^{*}}{\text { GOT }}$} & \multicolumn{2}{|c|}{$\begin{array}{l}\text { LDH } \\
\mathbf{U} / 1^{*}\end{array}$} & \multirow{2}{*}{$\begin{array}{c}\text { Arginase } \\
\text { IU† } \\
\text { Last } \\
\text { 130d }\end{array}$} \\
\hline & Total & Albumin & $\begin{array}{l}\text { First } \\
125 d\end{array}$ & $\begin{array}{l}\text { Last } \\
110 \mathrm{~d}\end{array}$ & $\begin{array}{l}\text { First } \\
125 d\end{array}$ & $\begin{array}{l}\text { Last } \\
110 \mathrm{~d}\end{array}$ & \\
\hline \multicolumn{8}{|l|}{ No-Mo } \\
\hline $\begin{array}{l}\text { Mean } \\
\text { SEM }\end{array}$ & $\stackrel{61}{0.83}$ & $\begin{array}{l}36 \\
1.00\end{array}$ & $\begin{array}{l}97 \\
15\end{array}$ & $\begin{array}{r}161 \\
57\end{array}$ & $\begin{array}{r}952 \\
90\end{array}$ & $\begin{array}{r}1134 \\
153\end{array}$ & 240 \\
\hline \multicolumn{8}{|l|}{ Low-Mo } \\
\hline Mean & 60 & 34 & 90 & 98 & 871 & 923 & 119 \\
\hline SEM & 0.79 & 0.96 & 16 & 15 & 86 & 62 & - \\
\hline \multicolumn{8}{|l|}{ Medium-Mo } \\
\hline Mean & 62 & 34 & 70 & 75 & 792 & 772 & 113 \\
\hline SEM & $1 \cdot 37$ & 1.23 & 12 & 5 & 38 & 32 & - \\
\hline \multicolumn{8}{|l|}{ High-Mo } \\
\hline Mean & 63 & 37 & 75 & 88 & 812 & 879 & 122 \\
\hline SEM & 0.99 & 1.00 & 10 & 12 & 23 & 46 & - \\
\hline
\end{tabular}

* $1 \mathrm{U}$ indicates the amount of enzyme which brings about the reaction of $1 \mu \mathrm{M}$ substrate/min.

$\dagger 1 \mathrm{IU}$ of arginase activity is the amount of arginase required to form $1 \mu \mathrm{M}$ urea/h.

the trial. Average values per treatment at different stages of the trial are presented in Table 5. No statistical analyses were done on these results because individual animals within groups showed dramatic increases in enzyme levels, resulting in non-uniform distribution of the results. Elevated enzyme levels were observed in five of the eight sheep in the high-Cu, no-Mo treatments. In two of these sheep the increases were quite dramatic and were first recorded $110 \mathrm{~d}$ before the end of the trial. The result was that the mean enzyme levels of this group were well above the levels observed in the other groups. However, none of the sheep succumbed to or showed any other signs of $\mathrm{Cu}$ toxicity. Slightly-elevated enzyme levels were measured in one sheep each from the low- and high-Mo treatment groups; the sheep in the high-Mo group showed the elevated enzyme levels from the onset of the trial. This result appears to be unrelated to any treatment effect.

\section{DISCUSSION}

An increase in hepatic $\mathrm{Cu}$ content due to Mo supplementation, as observed at the high levels of dietary Mo, is contrary to the accepted behaviour of the $\mathrm{Cu}-\mathrm{Mo}-\mathrm{S}$ interaction in sheep (Dick, 1954; Wynne \& McClymont, 1956; Ross, 1966). The fact that this increase was observed only at the higher dietary levels of Mo, suggests that it corresponds with the so-called systemic effects of the $\mathrm{Cu}-\mathrm{Mo}-\mathrm{S}$ interaction as observed in the plasma and kidneys (Dick, 1956; Suttle, 1974; Van Ryssen \& Stielau, 1980). These elevated Cu levels in the kidneys and plasma have been suggested to be the result of the accumulation of $\mathrm{Cu}-\mathrm{Mo}$-containing compounds in these tissues in forms unavailable to the body (Suttle, 1974). The high correlations between $\mathrm{Cu}$ and Mo in the kidneys as observed by Bremner \& Young (1978), Van Ryssen \& Stielau (1980) and in the present trial support the suggestion of Suttle (1974).

In the present trial, at a fixed level of S, Mo concentrations in the tissues followed a pattern of accumulation which corresponded to the daily Mo intake, an observation similar to that of Lesperance \& Bohman (1963). Grace \& Suttle (1979) demonstrated that poorly- 
exchangeable Mo compounds, formed with high Mo plus $\mathbf{S}$ intakes, were ineffectively excreted by either the urinary or faecal routes in sheep and suggested that the poor excretion of $\mathrm{Mo}$ was due to the formation of $\mathrm{Cu}$-containing thiomolybdates in ruminants.

The results of the present trial may suggest that complexes containing $\mathrm{Cu}$ and $\mathrm{Mo}$ tend to accumulate mainly in the kidneys but at high Mo intakes also in the other organs, provided high levels of $\mathrm{Cu}, \mathrm{Mo}$ and $\mathrm{S}$ are fed to sheep. In the present trial the accumulation of $\mathrm{Cu}$ in tissues took place at Mo intakes less than $60 \mathrm{mg} / \mathrm{sheep}$ per $\mathrm{d}$. When high concentrations of the proposed $\mathrm{Cu}$-Mo complexes accumulate in tissues, e.g. in the kidneys, there is a close relationship between $\mathrm{Cu}$ and Mo concentrations. However, the presence of other forms of $\mathrm{Cu}$ in other tissues will mask any measurable relationship between $\mathrm{Cu}$ and Mo in these tissues, e.g. the liver.

The accumulation of $\mathrm{Cu}$ in tissues, especially the liver, at high Mo intakes has been reported in non-ruminants (Miller et al. 1956; Mills, 1960; Arthur, 1965; Dale et al. 1973). The formation of compounds containing $\mathrm{Cu}$ and $\mathrm{Mo}$ in the proportion 1.5:1 was observed by Mills \& Mitchell (1971) in liver tissues of rats receiving high levels of $\mathrm{Cu}$ and Mo. Suttle (1974) concluded from work on non-ruminants, that dietary Mo concentrations below $100 \mathrm{mg} / \mathrm{kg}$ food would decrease the Cu status of the animal, but above $100 \mathrm{mg} \mathrm{Mo} / \mathrm{kg}$ food the more familiar response, namely increased tissue $\mathrm{Cu}$ concentrations accompanied by symptoms of clinical $\mathrm{Cu}$ deficiency, pertains.

In ruminants the concept that $\mathrm{Cu}$ and Mo may be present in the body in unavailable forms seems to be accepted (Cook et al. 1966; Ward, 1978). However, if Cu levels are only measured in the liver, kidney and plasma and at only two levels of Mo supplementation (Van Adrichem, 1965; Ross, 1966, 1970; Marcilese et al. 1969; Van der Berg \& van der Schee, 1973; Bremner \& Young, 1978), the accumulation of Cu in tissues, except the kidneys and plasma, may not be detected. Any accumulation of bound $\mathrm{Cu}$ in the liver will not be noticeable due to a concomitant decrease in total live $\mathrm{Cu}$ content brought about by $\mathrm{Mo}$ supplementation; this decrease may be more rapid than the $\mathrm{Cu}$ accumulation. The continuous decrease in hepatic $\mathrm{Cu}$ content in cattle at increasing levels of dietary Mo, as reported by Vanderveen \& Keener (1964) and Huber et al. (1971) may have been due to the lack of $\mathrm{Cu}$ in the diet. In the present trial no sign of $\mathrm{Cu}$ deficiency was observed in any of the haematological factors tested or in the $\mathrm{Cu}$ content of any tissues.

Dick (1954) observed a constant hepatic $\mathrm{Cu}$ retention in sheep at Mo intakes of between 20 and $100 \mathrm{mg} /$ sheep per $\mathrm{d}$. With an $S$ intake of $0.46 \mathrm{~g} / \mathrm{sheep}$ per $\mathrm{d}$ in that trial, it is possible that $\mathrm{S}$ was a limiting factor for the full expression of the $\mathrm{Cu}-\mathrm{Mo}-\mathrm{S}$ interaction. In contrast $S$ intake in the present trial was more than $3 \mathrm{~g} /$ sheep per $\mathrm{d}$.

Although liver $\mathrm{Cu}$ levels are considered to be useful indicators of the $\mathrm{Cu}$ status of ruminants (MacPherson \& Hemingway, 1965; Ross, 1966), it is clear from the present trial that liver $\mathrm{Cu}$ levels may become unreliable factors at very high Mo intakes.

After the commencement of Mo feeding in the present trial, two sheep experienced diarrhoea for a few days. Severe diarrhoea was observed by Suttle \& Field (1968) in sheep receiving $50 \mathrm{mg} \mathrm{Mo}$ and $10 \mathrm{~g}$ sulphate $/ \mathrm{kg}$ food. Diarrhoea as a sign of molybdenosis is usually observed only in cattle fed on high-Mo rations (Cunningham \& Hogan, 1959; Underwood, 1977; Ward, 1978). A reduction in plasma protein was suggested by Smith \& Wright (1975) as indicating that Mo supplementation affected protein metabolism. No differences in plasma protein or albumin were observed in the present trial. Bremner \& Young (1978) suggested that the accumulation of Mo in the tissues and plasma had a toxic effect and was the reason for reduced growth rates observed in sheep receiving additional Mo. It is possible that the forms in which Mo accumulated in tissues in sheep in the present trial were different from those observed by Bremner \& Young (1978) with low S intakes, explaining why growth was not affected. 
It is believed that the Mo in the tissues of the sheep in the present trial accumulated in forms unavailable to the body. Any form of tissue damage or interference with protein metabolism due to the presence of Mo therefore seems unlikely. This is supported by evidence from the plasma enzyme levels where little change was observed in any of the Mo-supplemented groups. Elevated enzyme levels were observed in some of the sheep on the high- $\mathrm{Cu}$ and no-Mo treatments. From the plasma arginase levels it may be concluded that tissue damage took place mainly in the livers of the affected sheep (Van Adrichem, 1965; Ross, 1966). The extended period during which these elevated enzyme levels were observed without the occurrence of a haemolytic crisis due to $\mathrm{Cu}$ toxicity is contrary to the maximum period of 8 weeks reported before a haemolytic crisis can be expected (Todd \& Thompson, 1963; Ross, 1966).

The authors wish to thank Mr B. D. Thring for attending to the sheep during the trial and Mrs R. Hill for laboratory assistance.

\section{REFERENCES}

Arthur, D. (1965). J. Nutr. 87, 69.

Barden, P. J. \& Robertson, A. (1962). Vet. Rec. 74, 252.

Bracewell, C. D. (1958). Vet. Rec. 70, 342.

Bremner, I. \& Young, B. W. (1978). Br. J. Nutr. 39, 325.

Cook, G. A., Lesperance, A. L., Bohman, V. R. \& Jensen, E. H. (1966). J. Anim. Sci. $25,96$.

Cornelius, C. E. \& Karneko, J. J. (1963). Clinical Biochemistry of Domestic Animals. New York: Academic Press.

Cunningham, I. J. \& Hogan, K. G. (1959). N.Z. Jl agric. Res. 2, 134.

Dale, S. E., Ewan, R. C., Speer, V. C. \& Zimmerman, D. R. (1973). J. Anim. Sci. $37,913$.

Dick, A. T. (1954). Aust. J. agric. Res. 5, 511.

Dick, A. T. (1956). In Inorganic Nitrogen Metabolism, p. 445 [W. D. McElroy and B. Glass, editors]. Baltimore: Johns Hopkins Press.

Grace, N. D. \& Suttle, N. F. (1979), Br. J. Nutr. 41, 125.

Huber, J. T., Price, N. O. \& Engel, R. W. (1971). J. Anim. Sci. 32, 364.

Huisingh, J. \& Matrone, G. (1976). In Molybdenum in the Environment, vol. 1, p. 125 [W. R. Chappell and K. K. Petersen, editors]. New York: Marcel Dekker Inc.

Lesperance, A. L. \& Bohman, V. R. (1963). J. Anim. Sci. 22, 686.

MacPherson, A. \& Hemingway, R. G. (1965). J. Sci. Fd Agric. 16, 220.

Marcilese, N. A., Ammerman, C. B., Valsecchi, R. M., Dunavant, B. G. \& Davis, G. K. (1969). J. Nutr. $99,177$.

Miller, R. F., Price, N. O. \& Engel, R. W. (1956). J. Nutr. 60, 539.

Mills, C. F. (1960). Proc. Nutr. Soc. 19, 162.

Mills, C. F. \& Mitchell, R. L. (1971). Br. J. Nutr. 26, 117.

Rayner, A. A. (1967). Biometry for Agriculture Students. Pietermaritzburg: University of Natal Press.

Ross, D. B. (1966). Br. vet. J. 122, 279.

Ross, D. B. (1970). Res. vet. Sci. 11, 295.

Schwartz, M. K. (1971). Clinical aspects of arginase. In Methods in Enzymology, vol. 17B, p. 857 [P. Colowick and N. O. Kaplan, editors]. New York: Academic Press.

Smith, B. S. W. \& Wright, H. (1975). Clinica chem. Acta 62, 55.

Suttle, N. F. (1974). Proc. Nutr. Soc. 33, 299

Suttle, N. F. (1975). Br. J. Nutr. 34, 411 .

Suttle, N. F. \& Field, A. C. (1968). J. comp. Path. 78, 351.

Todd, J. R. \& Thompson, R. H. (1963). Br. vet. J. 119, 161.

Underwood, E. J. (1977). Trace Elements in Human and Animal Nutrition, 4th ed. New York: Academic Press.

Van Adrichem, P. W. M. (1965). Tijdschr. Diergeneesk. 90, 1371.

Van der Berg, R. \& van der Schee, W. (1973). Tijdschr. Diergeneesk. 97, 378.

Vanderveen, J. E. \& Keener, H. A. (1964). J. Dairy Sci. 47, 1224.

Van Ryssen, J. B. J. (1979). S. Afr. J. Anim. Sci. 9, 21.

Van Ryssen, J. B. J. \& Stielau, W. J. (1980). S. Afr. J. Anim. Sci. 10, 49.

Ward, G. M. (1978). J. Anim. Sci. 46, 1078.

Wynne, K. N. \& McClymont, G. L. (1956). Aust. J. agric. Res. 7, 45. 